\title{
2. Solidarity in Europe: a comparative account of citizens' attitudes and practices
}

\author{
Maria Grasso and Christian Lahusen
}

\subsection{INTRODUCTION}

Solidarity has received heightened attention in recent times due to the various crises that have affected the European Union since 2008. Critical voices have repeatedly raised concerns that solidarity is severely at risk within the EU because of the inability of the European institutions and member states to agree on mechanisms of burden-sharing. Evidence for this is found in regard to the economic and financial crisis that has affected several European countries. Even though the European Union has developed a number of policy measures (e.g., the European Financial Stability Facility, the European Stability Mechanism, and the Stability and Growth Pact) which have opened the door to financial assistance, the EU has remained committed to bail-out policy packages that delegate financial liabilities and risks to nation-states threatened by bankruptcy. As a consequence, most commentators shared the conviction that international solidarity was dead (see Balibar, 2010; Habermas, 2017). A similar conclusion was drawn in regard to the increased influx of refugees from Syria and other regions affected by wars, and the inability of EU institutions and its member states to agree on a coordinated asylum policy, on quotas and on mechanisms of admission and integration. Consensus could only be reached in regard to the external dimension (e.g., border controls, the fight against human trafficking), leaving the issue of internal coordination unsolved.

The success of populist parties, the Brexit vote, and the mobilisation of Eurosceptic and xenophobic protests across Europe (e.g., Kriesi and Pappas, 2015) have raised further concerns that European solidarity might be at risk in a more fundamental and far-reaching manner. In times of crisis, we might not only be witnessing the erosion of cooperation and solidarity between member state governments, but also the corrosion 
of solidarity at the level of the European citizenry, thus threatening the social foundations of solidarity on which EU institutions and policies are built. In this regard, we might even expect that European solidarity is becoming even more fragile, restrained and contested at the level of the European population. Do these observations and concerns mirror the current situation throughout the European Union? Is European solidarity an ideal shared by the European citizenry? And how do we explain these differentiations; that is, can we identify factors responsible for further and/ or limiting solidarity within the European population?

We are urgently in need of empirical evidence in order to answer these questions. Public debates and conflicts continue to return to this issue but we have had very little empirical evidence on which to draw to inform this debate. Previous research has painted a mixed picture. On the one side, it seems true that the various crises affecting the EU are putting European solidarity under strain. Possibly, it is easier to profess cooperation in times of economic growth and optimistic economic outlooks, while solidarity might turn out to be more difficult to sustain in times of recession and scarcity. This is particularly true given that populist and xenophobic political entrepreneurs can draw on the exacerbation of citizens' fear and grievances and that the crisis overlaps with a long history of ineffective policies in key domains, such as poverty and unemployment, immigration and asylum. Consequently, political debates are marked increasingly by antagonism, conflict and mistrust between governments and citizens. On the other hand, 60 years of European integration have gradually established feelings of belongingness to the European community, and have enabled shared identification with European institutions, as well as European and cosmopolitan identities (Delanty and Rumford, 2005; Beck and Grande, 2007). Moreover, European integration has furthered cross-national experiences and contacts among citizens, as well as transnational trust between European peoples (Delhey, 2007). Finally, public opinion polls show that, in the midst of the European crisis, a majority of respondents still agree that it is desirable to give financial help to other countries in the name of European solidarity between member states (see Eurobarometer data, 2011, 76.1; Lengfeld et al., 2012; Gerhards et al., 2018).

This chapter aims to shed more light on this debate by presenting some key findings in this respect from an original population survey conducted in late 2016 among citizens of eight European countries (Denmark, France, Germany, Greece, Italy, Poland, Switzerland, and the UK) to analyse questions of solidarity in Europe. The survey was conducted as part of the TransSOL project. The questionnaire was administered in the relevant languages to approximately 2,000 respondents in each of the countries of the project (Total N 16,000). Respondent samples were 
matched to national statistics with quotas for education, age, gender and region, and population weights were applied where relevant. The questionnaire aimed to address the major dimensions of solidarity, both attitudinal and behavioural, as well as key independent variables. More information about the survey and the country-specific findings is available through the project's website (see reports on the website: http://transsol.eu/).

In this chapter, we analyse data with two major objectives in mind. First, we wish to present evidence on data reflecting the readiness of European citizens to support European solidarity both in terms of activities and attitudes. For this purpose, we will look at levels of civic solidarity across the eight countries under study, and we will compare levels of support for European solidarity in comparison with other potential targets (national and global solidarity). Second, we will engage in an analysis of these findings, particularly with respect to identifying those individual factors such as socio-demographic traits, political attitudes, and cultural values that are linked to the likelihood among European citizens to engage in acts of solidarity at the European level. As such, we are interested in examining the potential cleavages nurturing public contentions with respect to European solidarity within the European population. The structure of this chapter follows the main objectives outlined. In Section 2.2, we present and discuss previous research in order to make sense of the complexity of the phenomenon under study and develop our hypotheses for analysis. We also present the main concepts and hypotheses leading to our empirical analysis. In Section 2.3, we turn to the two research objectives, namely the descriptive account of European solidarity at the level of the European population, and the explanatory analysis for contributing factors. In Section 2.4, we summarise the key findings and discuss potential implications of the research.

\subsection{CONTRIBUTING KNOWLEDGE TO AN ESTABLISHED FIELD OF RESEARCH: CONCEPTS AND OBJECTIVES}

Solidarity is one of the key phenomena studied in the social sciences. For many decades, scholars from sociology, economics, political science and psychology, among others, have inquired into the forms and conditions of solidarity, even though our knowledge is quite limited with respect to the transnational dimension, such as, for example, European-level solidarity. This lacuna is even more serious once we move to the individual level and look at attitudes and practices of European citizenry with respect to European solidarity. How strongly is the idea of solidarity shared 
by citizens throughout Europe, and to what extent are they engaged in solidarity-related activities? Is solidarity limited to specific communities or target groups, and what is the importance of solidarity among Europeans? What can we say about the social traits, beliefs and convictions of people engaged in solidarity activities? And which are the factors inhibiting solidarity dispositions and practices?

A review of available studies is important in this respect to lay the theoretical groundwork for the following analyses. First of all, previous research is important in conceptual terms, given that we need to define what the notion of solidarity is all about. In this regard, we converge with a strong strand of research that defines solidarity as the preparedness to share one's own resources with others and/or support state redistributive policies (e.g., Stjernø, 2012: 2). This proposal stresses one element that has received much attention in the social sciences: namely, attitudes and dispositions. In fact, most surveys are primarily interested in measuring the readiness of citizens to share some of their resources with others, and here, a recurrent topic was the support for redistributive (social) policies and the willingness of respondents to devote their taxes to these means (Svallfors, 1997; Fong, 2001; Amat and Wibbels, 2009; Rehm, 2009; Rehm et al., 2012). This aspect is crucial for European societies, given the prominence of welfare institutions and social policies as institutionalised forms of solidarity. However, we cannot be sure that whether these lessons also apply at the European level, because public support of welfare institutions and social policies might also lead to opposition towards European policies of redistribution, as they might curtail or endanger national solidarity.

Research into redistributive preferences among citizens is an important contribution to understanding the extent to which the welfare state is rooted in society. However, our own research needs to enlarge the focus in three directions to grasp the role and place of European solidarity. First, attitudes and dispositions do not determine actual practices (e.g., Maio et al., 2006). This means that the analysis of solidarity dispositions within the European population helps to paint only a partial picture of European solidarity. Our own survey aimed more explicitly to measure reported activities in order to get a more reliable picture of the extent to which European citizens are committed to supporting others within and beyond their countries and communities.

Second, scholarly writing has tended to focus on (financial) help for the needy, thus privileging the charitable or philanthropic dimension of solidarity. While this aspect seems to be closely related to solidarity in the public understanding, it nonetheless ignores the political dimension of solidarity. In fact, people demonstrate solidarity with other persons in need when participating in collective actions (e.g., public claims-making, 
political protests, communication campaigns) that strive to improve the situation of these groups by mobilising public support, committing stakeholders and/or changing public policies on their behalf (Giugni and Passy, 2001). Particularly in the context of the EU, it is important to include this dimension of solidarity (Balme and Chabanet, 2008; Lahusen, 2013; Baglioni and Giugni, 2014; Giugni and Grasso, 2019). European solidarity is already present when people help other European citizens make themselves heard, particularly if we are speaking of social groups at the fringes of society that are not only exposed to social exclusion, but also to political marginalisation and invisibility in terms of news coverage and interest representation.

Third, our project confirms results of previous research, namely that solidarity is of little analytic and practical use when conceived of as a generalised disposition or practice. Studies recurrently highlight that solidarity is conditional and thus tied to specific issues and target groups (Komter, 2005). Solidarity is related to ideas about the neediness, deservingness or social proximity of targeted groups. These targets can be vulnerable groups within society, such as the elderly, the unemployed or the disabled (van Oorschot, 2006), but also entire countries, such as the European member states affected by the 2008 economic crisis (Lengfeld et al., 2012).

The research design of our survey reflected these conceptual clarifications. First, our questionnaire included questions addressing attitudes and dispositions related to solidarity, but also asked respondents to list reported activities. In asking questions about which types of solidarity-related activities individuals engaged in, we tried to be more demanding than previous studies by assembling information about various activities, ranging from boycotting products to active participation in voluntary associations. Second, the survey was conceived to measure not only the charitable dimension of solidarity, but also the political aspects indicated above. For this purpose, questions were developed on a rights-based concept of solidarity by asking respondents whether they actively supported the rights of various groups. Additionally, we assembled information on political activities and orientations related to solidarity, ranging from protest participation to policy related issues (e.g., European solidarity measures). Third, the survey aimed at gathering data on the 'vertical' and 'horizontal' dimension of solidarity. To this end, on the one hand, it included questions measuring the support of respondents for redistributive policies within their country and at the EU level. On the other hand, it asked respondents to indicate their involvement in interpersonal forms of help and support. Finally, we also looked at whether solidarity dispositions and practices were generalised and/or bound to certain target groups. For this purpose, we differentiated between a spatial dimension (i.e., solidarity with people 
within the respondents' countries, within the EU, and beyond the EU) and an issue-related dimension by addressing three different target groups (i.e., the refugees/asylum seekers, the unemployed and the disabled).

These conceptual clarifications are important in order to unravel the complex phenomenon of solidarity and develop measurement instruments that are able to grasp the various dimensions of solidarity. They also helped to identify basic assumptions guiding our descriptive analysis. In fact, previous research can be used to formulate three descriptive hypotheses. First, we expect that citizens will be more inclined to support institutionalised forms of solidarity (e.g., in terms of social policies and their objectives), when compared with the number of citizens engaged in solidarity action themselves. Second, we expect that civic solidarity action might be stronger in regard to the philanthropic or charitable dimension, and weaker in regard to overly political aspects, such as participation in political protest actions. Third, we assume that solidarity towards other Europeans will be less strongly diffused in the population, when compared to solidarity among fellow citizens and other groups of the population that are considered to be closer and more needy.

Beyond these descriptive aims, our analyses will also be devoted to the identification of explanatory factors that support solidarity at large and European solidarity in particular. Also, in this regard, our survey followed knowledge on the subject previously accumulated in scholarship. Many studies converge in the observation that civic or social solidarity among citizens is highly patterned by a series of factors, such as socio-demographic traits and social-structural factors, political allegiances and social capital, religious beliefs and values among others. In order to systematise this evidence, we propose to group these studies into three strands of inquiry as follows.

A first source of inspiration comes from empirical research on redistributive preferences. These studies are interested in identifying those factors that guarantee the support of citizens for the welfare state at large and various social policies in particular, and thus spur the backing of institutionalised forms of wealth redistribution and help (Svallfors, 1997; Fong, 2001; Amat and Wibbels, 2009; Rehm, 2009; Alesina and Giuliano, 2011; Rehm et al., 2012). Studies have addressed a variety of social policy fields, among them pensions (Jaime-Castillo, 2013), poverty (Alesina and Glaeser, 2004; Scheepers and Grotenhuis, 2005) and immigration (Banting and Kymlicka, 2006; Mau and Burkhardt, 2009). More recent studies have expanded the focus onto the European level by analysing public support for redistributive policies within the EU (Mau, 2005; Baute et al., 2018; Gerhards et al., 2018). Evidence suggests that support for redistributive preferences is influenced by the respondents' position in society, e.g., 
the rational calculations tied to their state of vulnerability (Iversen and Soskice, 2001; Rehm, 2009) but that cognitive and cultural factors also play a role (Mau, 2005). Research has pointed to the role of religion and religiosity (Stegmueller et al., 2012; Lichterman, 2015), but also general beliefs about the causes of income inequality (Fong, 2001) and perceptions of deservingness (van Oorschot, 2006). With respect to the latter, research has identified several criteria that influence the judgement of deservingness: (1) the level of perceived responsibility and neediness, (2) social and spatial proximity and identity, including loyalties to ethnic groups, (3) the recipients' attitudes and the degree of reciprocation (receiving and giving) (van Oorshot, 2000, 2006; Luttmer, 2001; Alesina and Glaeser, 2004).

Second, the extensive field of studies on social capital and social cohesion is relevant for our discussion here since it focuses on topics that are closely interrelated to (transnational) solidarity. In this field, we find studies that are interested in forms of interpersonal help and support, which highlight the importance of (interpersonal and institutional) trust, and which emphasise the importance of memberships and active participation in civic associations and groups (Putnam et al., 2003; van Oorschot et al., 2006) for the development of reciprocal trust and the bedrock of wellfunctioning democratic societies. In all these areas, the assumption is that social capital is the necessary 'glue' for social cohesion (Jeannotte, 2000; Chan et al., 2006; Delhey, 2007), and thus also essential for understanding the conditions, structures and dynamics underpinning solidarity. Similar conclusions to the above-stated research have been made in regard to the conditioning factors. Civic engagement is more diffused within the middle and upper social classes - it is tied back to post-materialist values and religious beliefs; at the same time, it is less common in societies with social cleavages, political conflicts and more residual welfare state institutions (Kumlin and Rothstein, 2005; van Oorschot and Arts, 2005; Gesthuizen et al., 2008; Gelissen et al., 2012).

Finally, there are also lessons to be drawn from research on political behaviour in general, and social movement and protest participation more specifically. These strands of research focus on the political dimensions of solidarity. Scholarly writing seems to support some of the research assumptions presented before, by showing how political behaviour is patterned by social inequalities and forms of social exclusion (Brady et al., 1995; Kronauer, 1998). Moreover, studies agree on the fact that solidarity is also highly patterned by political preferences and orientation, e.g., along the left-right scale (Likki and Staerklé, 2014). Social movement analysis adds relevant knowledge by pointing to the importance of mobilisation processes led by existing organisations and groups, with the latter considered as collective means of mobilising, organising and perpetuating 
(transnational) solidarity in terms of binding norms, commitments and behaviours (Smith 1997; Balme and Chabanet, 2008; della Porta and Caiani, 2011; Baglioni and Giugni, 2014). That is, being a member or follower of a certain initiative, association, organisation or movement implies a commitment not only to specific norms of solidarity, but also to palpable acts as well (e.g., membership fees and charitable donations, joint political protests, events of claims-making).

Based on these insights, we will try to identify those factors impinging on European solidarity, both in terms of activities and attitudes. We propose to test a number of hypotheses that emanate from the previously presented research strands. First, we assume that European solidarity is restrained to a population group with similar socio-demographic traits. The study of civic engagement, for instance, has shown that voluntary engagement tends to replicate the public/private divide by centring more strictly on male-dominated and public activities, to the detriment of female networks of care and help (Neill and Gidengil, 2006; Valentova, 2016). It has been shown that younger and older citizens are more active in social movements, following different grades of biographical availability in the life course (Beyerlein and Bergstrand, 2013). And we know that migrants are often involved in cross-national networks of support and help (Glick Schiller et al., 1995; Morokvasic, 1999; Recchi and Favell, 2009). Hence, we hypothesise that European solidarity action is more likely among men $(\mathrm{H} 1)$; younger and older citizens $(\mathrm{H} 2)$; and those with a migrant background (H3).

Second, we test whether solidarity is patterned by the differential access of citizens to valued resources and skills, such as income and education, by the respondents' social status and affiliation to social class (Verba et al., 1978; Cainzos and Voces, 2010), and by different levels of social exclusion and deprivation (Kronauer, 1998). Following the lines of previous research, we thus hypothesise that European solidarity activities will be more diffused among respondents with higher resources such as those from professional classes and those with higher levels of educational attainment (H4).

Third, solidarity should be supported through higher levels of social capital, following the propositions of research devoted to civil society and social movements (Jenkins, 1983; Putnam et al., 2003; van Oorschot et al., 2006). In this respect, we assume that European solidarity will be prevalent among respondents with higher rates of interpersonal trust and associational involvement in a wide range of social, cultural and political organisations (H5).

Fourth, European solidarity might be tied back to political activities and attitudes, such as conventional forms of political participation and 
ideological orientations (e.g., Blekesaune and Quadagno, 2003; Amat and Wibbels, 2009; Likki and Staerklé, 2014). In this sense, we would expect that European solidarity might be more likely among respondents that are interested in politics (H6), regularly participate in elections $(\mathrm{H} 7)$ and also among those who are more leftist (H8).

Finally, previous research has insisted on the role of normative orientations and collective identities that might condition levels of (European) solidarity (Luttmer, 2001; Komter, 2005; Stets and McCaffree, 2014). On the one hand, this might apply to religion and religiosity (Stegmueller et al., 2012; Lichterman, 2015), assuming that religious citizens might be more inclined to act in support of the needy, both in charitable and political terms, and thus also in support of fellow Europeans. On the other hand, it is very likely that citizens with a stronger sense of belongingness to Europe might be more often involved in acts of solidarity with fellow Europeans. Thus, we expect that European solidarity action is more likely among citizens with stronger religious attachments (H9) and a stronger attachment to Europe (H10).

\subsection{EUROPEAN SOLIDARITY: EMPIRICAL EVIDENCE FROM EIGHT EUROPEAN COUNTRIES}

The online survey conducted by the TransSOL project in November and December 2016 provides systematic data to depict and analyse public support of European solidarity in its various dimensions. In the following, we will begin with a description of levels of civic solidarity in the eight countries under analysis, first for individual attitudes, and second in regard to reported activities, before we move on to an explanatory analysis that aims to test the hypotheses introduced above.

\subsubsection{Public Support for European Solidarity: A Descriptive Account}

The conceptual discussion of previous research has highlighted the need for a differentiated analysis of European solidarity. On the one hand, we need to distinguish between attitudes and reported activities; on the other hand, we have to compare levels of solidarity within Europe with other potential targets of solidarity, both in spatial and social terms. For this purpose, we will present findings on a number of questions that are closely related to solidarity preferences, before we move on to reported activities.

In regard to attitudes, we can rely on a series of questions that are aimed at measuring the public support for redistributive policies within countries, 
Table 2.1 Eliminating inequalities. Eliminating big inequalities in income between citizens

\begin{tabular}{lccccc}
\hline & $\begin{array}{c}\text { Not at all } \\
\text { important } \\
(\%)\end{array}$ & $\begin{array}{c}\text { Not very } \\
\text { important } \\
(\%)\end{array}$ & Neither $(\%)$ & $\begin{array}{c}\text { Fairly } \\
\text { important } \\
(\%)\end{array}$ & $\begin{array}{c}\text { Very } \\
\text { important } \\
(\%)\end{array}$ \\
\hline Denmark & 5.4 & 12.7 & 33.1 & 32.8 & 16.0 \\
France & 2.4 & 5.8 & 20.3 & 37.5 & 34.0 \\
Germany & 2.0 & 6.2 & 22.8 & 39.3 & 29.7 \\
Greece & 1.8 & 3.5 & 16.7 & 35.1 & 42.9 \\
Italy & 1.4 & 3 & 14.9 & 40 & 40.7 \\
Poland & 2.6 & 5.4 & 21.7 & 36.5 & 33.8 \\
Switzerland & 3.2 & 7.9 & 22.3 & 38.9 & 27.7 \\
UK & 3.6 & 6.7 & 28.5 & 35.8 & 25.4 \\
Total & 2.8 & 6.5 & 22.6 & 37.0 & 31.1 \\
\hline
\end{tabular}

Source: TransSOL (Horizon 2020, GA, no. 649435)

between EU member states and in relation to developing countries. As we will see, there is more diffused support for policies of redistribution between fellow citizens than with Europeans or non-Europeans. In fact, European citizens largely agree that solidarity is a high value to which a society should be committed. Our respondents were asked to identify the objectives and measures a fair society should be committed to. Here, we wish to present their responses on two items: eliminating income inequalities, and providing services guaranteeing that basic needs are met.

Table 2.1 shows that European citizens strongly support the general objective of redistributive public policies with $68 \%$ considering the reduction of big income inequalities as an important goal. National differences are not very strong, thus unveiling that there seems to be a shared consensus on the need to keep a social model alive everywhere in Europe. Smaller deviations occur between the more generous and the more residual welfare states: many more Danish respondents agree that the elimination of inequalities is not important (i.e., 18.1\%), when compared to the small minority of Greek and Italian citizens agreeing to the same statement (i.e., $5.3 \%$ and $4 \%$, respectively). These deviations seem to mirror the differing national contexts: in a more generous welfare state, the elimination of inequalities seems to be less important than in countries where the welfare state is less generous.

This broad public support for reducing income inequality shows that the idea of national solidarity seems to be widely diffused. And this support translates into a generalised support for political measures that aim to 
Table 2.2 Meeting basic needs. Guaranteeing that basic needs are met for all, in terms of food, housing, clothes, education, health

\begin{tabular}{lccccc}
\hline & $\begin{array}{c}\text { Not at all } \\
\text { important } \\
(\%)\end{array}$ & $\begin{array}{c}\text { Not very } \\
\text { important } \\
(\%)\end{array}$ & $\begin{array}{c}\text { Neither } \\
(\%)\end{array}$ & $\begin{array}{c}\text { Fairly } \\
\text { important } \\
(\%)\end{array}$ & $\begin{array}{c}\text { Very } \\
\text { important } \\
(\%)\end{array}$ \\
\hline Denmark & 1.1 & 2.2 & 14.5 & 44.0 & 38.2 \\
France & 1.4 & 2.6 & 14.6 & 39.7 & 41.7 \\
Germany & 1.0 & 2.8 & 11.8 & 36.2 & 48.2 \\
Greece & 0.8 & 1.3 & 5.7 & 23.4 & 68.8 \\
Italy & 0.9 & 2.4 & 11.8 & 31.6 & 53.3 \\
Poland & 1.8 & 3.6 & 17.8 & 33.0 & 44.0 \\
Switzerland & 1.4 & 3.0 & 14.8 & 34.2 & 46.6 \\
UK & 0.9 & 3.5 & 12.3 & 36.4 & 46.9 \\
Total & 1.2 & 2.7 & 12.9 & 34.9 & 48.3 \\
\hline
\end{tabular}

Source: TransSOL (Horizon 2020, GA, no. 649435)

guarantee a universal provision of services that allow the basic needs of the population to be met, such as food, housing, clothes, education and health. Table 2.2 summarises the responses, reasserting that a fair society has to provide a wide range of services. $83.2 \%$ of all respondents agree that these policies are important, while only $3.8 \%$ do not attribute importance to this. Also, in this regard, national differences are minimal; only the Greek respondents rally even more consensually in support of this statement $(92.2 \%)$.

These findings need to be put into context, because there are other spatial entities (the global and the European level) that might be pertinent targets of solidarity. In our survey, we aimed at measuring the degree of public commitment to the idea of supra-national solidarity by asking respondents whether they would support redistributive policy measures or programmes. Table 2.3 addresses the global level, and it shows that a strong majority of respondents supports the attempts of the EU to help countries outside Europe in fighting poverty and promoting development, with $62 \%$ supporting and only $14 \%$ opposing these measures. National differences are moderate, with Germans and Italians being most supportive (74\% and $72 \%$, respectively), and the Polish being the least committed (43\%). With the exception of Poland, however, there is a majority of citizens approving this kind of measure across the European countries analysed here.

As we move to the European level, we see that solidarity policies are less supported, and that public opinion is much more divided when it comes to the question of whether governments should engage in solidarity measures 
Table 2.3 Development aid. "The European Union provides development aid to assist certain countries outside the EU in their fight against poverty and in their development. How important do you think it is to help people in developing countries?"

\begin{tabular}{lccccc}
\hline & $\begin{array}{c}\text { Not at all } \\
\text { important } \\
(\%)\end{array}$ & $\begin{array}{c}\text { Not very } \\
\text { important } \\
(\%)\end{array}$ & $\begin{array}{c}\text { Neither } \\
(\%)\end{array}$ & $\begin{array}{c}\text { Fairly } \\
\text { important } \\
(\%)\end{array}$ & $\begin{array}{c}\text { Very } \\
\text { important } \\
(\%)\end{array}$ \\
\hline Denmark & 4 & 8 & 26 & 43 & 19 \\
France & 5 & 9 & 32 & 38 & 16 \\
Germany & 3 & 6 & 18 & 46 & 28 \\
Greece & 6 & 7 & 21 & 44 & 22 \\
Italy & 4 & 7 & 18 & 46 & 26 \\
Poland & 5 & 16 & 35 & 35 & 8 \\
Switzerland & 3 & 8 & 20 & 44 & 25 \\
UK & 6 & 9 & 27 & 37 & 21 \\
Total & 5 & 9 & 25 & 42 & 20 \\
\hline
\end{tabular}

Source: TransSOL (Horizon 2020, GA, no. 649435)

Table 2.4 Fiscal solidarity: pay public debts. "The EU is currently pooling funds to help EU countries having difficulties in paying their debts. To what extent do you agree or disagree with this measure?"

\begin{tabular}{lccccc}
\hline & $\begin{array}{c}\text { Strongly } \\
\text { disagree }(\%)\end{array}$ & $\begin{array}{c}\text { Disagree } \\
(\%)\end{array}$ & $\begin{array}{c}\text { Neither } \\
(\%)\end{array}$ & Agree (\%) & $\begin{array}{c}\text { Strongly } \\
\text { agree }(\%)\end{array}$ \\
\hline Denmark & 14 & 24 & 34 & 23 & 5 \\
France & 15 & 19 & 30 & 28 & 8 \\
Germany & 15 & 26 & 25 & 27 & 6 \\
Greece & 7 & 4 & 24 & 38 & 26 \\
Italy & 5 & 11 & 18 & 47 & 19 \\
Poland & 8 & 12 & 42 & 33 & 6 \\
Switzerland & 14 & 22 & 31 & 28 & 5 \\
UK & 18 & 23 & 25 & 27 & 7 \\
Total & 12 & 18 & 29 & 31 & 10 \\
\hline
\end{tabular}

Source: TransSOL (Horizon 2020, GA, no. 649435)

within the EU, thus corroborating previous findings by Mau (2005). In the case of fiscal solidarity measures in support of countries with public debts, Table 2.4 shows that supporters outweigh the opponents only slightly ( $41 \%$ vs. $30 \%$ ), with $29 \%$ undecided respondents. 
Table 2.5 Fiscal solidarity: help refugees. "Would you support or oppose your country's government offering financial support to the European Union in order to help refugees?"

\begin{tabular}{lccccc}
\hline & $\begin{array}{c}\text { Strongly } \\
\text { oppose }(\%)\end{array}$ & $\begin{array}{c}\text { Somewhat } \\
\text { oppose }(\%)\end{array}$ & $\begin{array}{c}\text { Neither } \\
(\%)\end{array}$ & $\begin{array}{c}\text { Somewhat } \\
\text { support }(\%)\end{array}$ & $\begin{array}{c}\text { Strongly } \\
\text { support }(\%)\end{array}$ \\
\hline Denmark & 16 & 17 & 25 & 27 & 14 \\
France & 26 & 19 & 29 & 21 & 5 \\
Germany & 12 & 17 & 24 & 35 & 12 \\
Greece & 24 & 15 & 23 & 31 & 8 \\
Italy & 21 & 25 & 28 & 23 & 4 \\
Poland & 18 & 19 & 33 & 24 & 5 \\
Switzerland & 21 & 25 & 20 & 28 & 6 \\
UK & 20 & 18 & 27 & 26 & 10 \\
Total & 20 & 19 & 26 & 27 & 8 \\
\hline
\end{tabular}

Source: TransSOL (Horizon 2020, GA, no. 649435)

Table 2.5 further shows that with respect to supporting refugees, the group against offering more funds for EU measures slightly outweighs the supporters (39\% vs. $35 \%$ ), again with a considerable share of respondents saying they neither agree nor disagree. The support is somewhat stronger in countries requiring help in the relevant crisis: i.e., support is stronger in Greece and Italy with regard to public debt, and higher in Germany, Greece and Denmark with regard to refugees.

These findings need to be interpreted prudently, because questions related to the national, global and European levels are not strictly comparable. The questions about national solidarity address fundamental issues of solidarity (inequalities and basic needs), while the question on the support for developing countries is related to humanitarian concerns and does not explicitly touch on the question of what fair distribution of wealth is. In the European case, however, respondents had to react to very specific questions about burden-sharing. What the data show is that European citizens are more reluctant to agree to sharing costs and responsibilities. This more reluctant posture, however, seems to be in line with previous studies (i.e., Mau, 2006), while deviating from the more optimistic findings of a recent study by Gerhards et al. (2018), who detected a wide support for both fiscal solidarity and redistributing the responsibility for refugees (both above 60\%). Findings here could in part be a result of different question wordings, given that the study by Gerhards et al. (2018) frames questions in more striking (severe debt crisis) and programmatic terms (the EU countries could tackle the refugee problem together), while 
our own questions leave more discretion for people to disagree with the obligation to help other European countries in dealing with their debts and with refugees. Such results thus show that European solidarity is not a generalised and robust disposition within the European population, but is rather marked by ambivalence and differentiation.

These differentiations seem to be marked particularly with respect to ideas of redistributive justice (Arts and Gelissen, 2001; de Witte, 2015). European citizens seem to be more reluctant to agree to binding policies of fiscal solidarity, because they tend to believe that these measures might infringe principles of distributive justice. In fact, the motives of people for supporting fiscal solidarity within the EU (see Table 2.6) show that the largest group subscribes to the idea of reciprocity and deservingness. According to these views, solidarity in the EU is an exchange relation of giving and receiving help. Moreover, groups receiving help need to show that they are worthy of being helped. European solidarity suffers immediately when citizens have the feeling that support measures are one-sided and that they could be potentially misused. This finding mirrors evidence from other studies on solidarity, which argue that the readiness to support others and/or to endorse redistributive measures by state actors is tightly linked to the ideas of reciprocity, fairness, trustworthiness and deservingness (see Wheeless, 1978; Thielemann, 2003; Lengfeld et al., 2015). Citizens who believe that the recipients of solidarity might not be trustworthy and deserving, and might not be committed to fair and reciprocal relations of mutual help, tend to qualify their readiness to engage in solidarity themselves.

\subsubsection{Reported Solidarity Action: A Descriptive Account}

The previous findings show that European citizens tend to subscribe generally to the ideals of solidarity and to the need to take care of basic needs and to reduce social inequalities. Enthusiasm is less marked as soon as we move closer to specific policy measures designed to further European solidarity, possibly since citizens might feel that these measures could infringe principles of distributive justice. The degree of public support, however, decreases more once we move from individual attitudes to the level of reported activities. As expected, we see that fewer respondents have engaged in support for other people or groups in their daily life, when compared with the percentage of respondents supporting redistributive policies and/or objectives.

Table 2.7 summarises this finding by listing the percentage of respondents that indicates having engaged in various solidarity activities in support of other people or groups. This question was asked in regard to different 


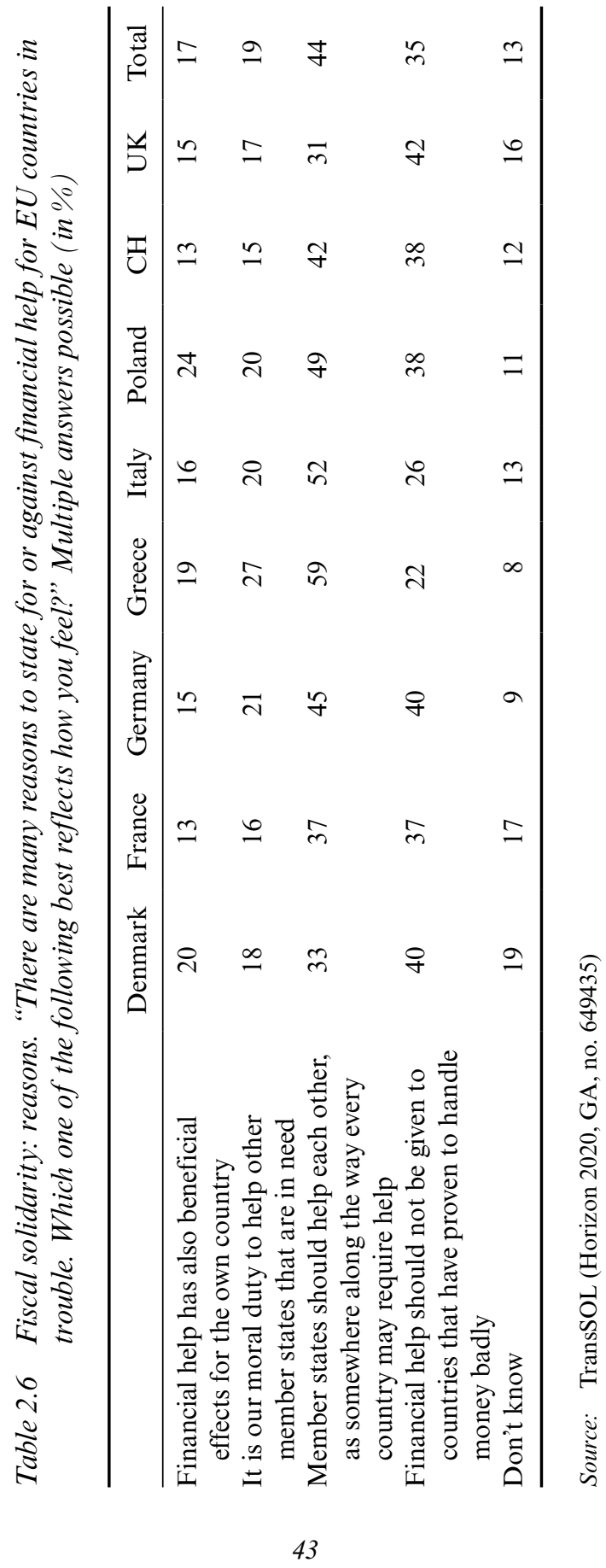


Table 2.7 Support of other people. "Have you ever done one of the following in order to support the rights of people/groups?"

\begin{tabular}{lcccccc}
\hline & $\begin{array}{c}\text { People in } \\
\text { your own } \\
\text { country } \\
(\%)\end{array}$ & $\begin{array}{c}\text { People } \\
\text { in other } \\
\text { countries } \\
\text { within the } \\
\text { EU (\%) }\end{array}$ & $\begin{array}{c}\text { People in } \\
\text { countries } \\
\text { outside the }\end{array}$ & $\begin{array}{c}\text { Disability } \\
\text { rights }(\%)\end{array}$ & $\begin{array}{c}\text { The } \\
\text { Enemployed } \\
(\%)\end{array}$ & $\begin{array}{c}\text { Refugees/ } \\
\text { asylum } \\
\text { seekers } \\
(\%)\end{array}$ \\
\hline Denmark & 47 & 23 & 35 & 44 & 27 & 30 \\
France & 47 & 25 & 30 & 50 & 24 & 20 \\
Germany & 51 & 31 & 40 & 52 & 27 & 34 \\
Greece & 62 & 35 & 36 & 62 & 58 & 36 \\
Italy & 47 & 32 & 33 & 49 & 36 & 28 \\
Poland & 59 & 35 & 37 & 65 & 40 & 27 \\
Switzerland & 59 & 34 & 45 & 67 & 33 & 33 \\
UK & 38 & 19 & 25 & 35 & 19 & 22 \\
Total & 51 & 29 & 35 & 53 & 33 & 29 \\
\hline
\end{tabular}

Note: At least one of the following was named: protest, donated money or time, bought or boycotted goods, passive or active membership

Source: TransSOL (Horizon 2020, GA, no. 649435)

addressees or target groups, ranging from fellow citizens to Europeans and non-Europeans. Additionally, we included three further groups of needy persons, namely the unemployed, refugees/asylum seekers and persons with disabilities, which were the focus of the TransSOL project's case studies. A majority of respondents have engaged in solidarity activities in support of people in their country $(51 \%)$, including donating money or time, protesting and engaging in voluntary associations. At the same time, however, citizens are less inclined to support other Europeans through solidarity actions $(29 \%)$, while a slightly higher percentage engaged in activities supporting non-Europeans (35\%). As to the three target groups, citizens have been more committed to helping people with disabilities, and least to supporting refugees/asylum seekers, though in some countries the figures for support of the unemployed are lower (Denmark, Germany, the UK) thus generally corroborating empirical evidence from previous studies on deservingness (von Oorschot, 2000, 2006).

The levels of practised solidarity do largely correspond to what previous research has noted in terms of country specific levels of civic engagement (e.g., Bauer et al., 2013). Of particular interest is the fact that Greek and Polish citizens (and to a lesser extent also Italians) exhibit high levels of participation in activities in support of people within and outside their 
Table 2.8 Support for other Europeans. "Have you ever done one of the following in order to support the rights of people/groups in other countries within the European Union?"

\begin{tabular}{lcrrccc}
\hline & Protest & $\begin{array}{c}\text { Donate } \\
\text { money }\end{array}$ & $\begin{array}{c}\text { Donate } \\
\text { time }\end{array}$ & Consumption & $\begin{array}{c}\text { Passive } \\
\text { membership }\end{array}$ & $\begin{array}{c}\text { Active } \\
\text { membership }\end{array}$ \\
\hline Denmark & 3.8 & 11.7 & 5.2 & 9.9 & 4.4 & 3.9 \\
France & 4.7 & 9.3 & 6.7 & 10.8 & 2.7 & 3.5 \\
Germany & 6.5 & 13.4 & 8.7 & 15.0 & 3.3 & 4.7 \\
Greece & 9.8 & 8.4 & 16.0 & 17.4 & 5.8 & 5.4 \\
Italy & 7.7 & 12.1 & 7.5 & 11.2 & 4.7 & 6.2 \\
Poland & 6.0 & 13.1 & 12.7 & 9.8 & 3.7 & 3.8 \\
Switzerland & 4.2 & 18.2 & 8.2 & 17.6 & 5.6 & 3.7 \\
UK & 3.2 & 8.6 & 4.0 & 5.4 & 3.3 & 3.0 \\
Total & 5.7 & 11.9 & 8.6 & 12.1 & 4.0 & 4.3 \\
\hline
\end{tabular}

Source: TransSOL (Horizon 2020, GA, no. 649435)

country. These rates are close to - or even higher than - levels of solidarity in the other, supposedly more active countries. This could reflect the situation of crisis, uncertainty and transition experienced in these countries. Particularly in the case of Greece, we know that the economic and financial crisis since 2008 - as well as the so-called refugee crisis of 2015/16 - have unleashed a wave of social solidarity initiatives (Sotiropoulos and Bourikos, 2014; Giugni and Grasso, 2016; Grasso and Giugni, 2016, della Porta, 2018). Also, in other countries, the support for refugees and asylum seekers is rather high, particularly when considering that in previous studies these target groups tended to come far behind other potential recipients (e.g., van Oorschot, 2000, 2006). This observation applies to Denmark, Germany, Greece and Switzerland. The dramatic hardship experienced by refugees on their way to and through Europe to their countries of destination incited a wave of welcoming initiatives in many countries (Evangelinidis, 2016). In this sense, our data reveals that European citizens tend to deliver in terms of voluntary engagement, also in times of crisis and in emergency situations.

If we look at specific activities engaged in to support fellow Europeans (Table 2.8), we can see that membership in associations and participation in street protests are the least common practices, with fewer than $6 \%$ of respondents engaged in these actions. Donating money and buying or boycotting products tend to be the most common activities. The Swiss and Germans are more active in donating money and buy/boycotting, while the Greeks and the Italians are more strongly involved in protest activities, the donation of time and active involvement in associations in support 
of other Europeans. These higher rates of activities seem to mirror the generalised mobilisation of Greek and Italian citizens in solidarity with others, thus demonstrating that there are links between target group and specific solidarity actions.

\subsubsection{Drivers of European Solidarity: An Explanatory Account}

Previous analyses have shown that solidarity practices in support of other Europeans are restricted to a smaller group of citizens, i.e., less than one out of three respondents (see Table 2.7). This observation leads to follow-up questions. Who are those citizens involved in European solidarity actions? Do those citizens share a common profile, e.g., in regard to socio-demographic traits, social-structural positions, political attitudes and cultural values? For this purpose, we wish to engage in a multivariate analysis that takes a closer look at the index variable measuring reported activities in support of other Europeans and explore the hypotheses introduced before with respect to possible drivers. To this end, we first look at descriptive statistics for each driver with respect to activism in support of fellow European citizens (Table 2.9) and then move to a regression model examining the relative importance of the various factors (Table 2.10).

With respect to our hypotheses, we look first at some preliminary evidence from the descriptive patterns. In Table 2.9 we can see that by and large $\mathrm{H} 1$ is confirmed in several countries with men more likely to engage in activism than women. With respect to $\mathrm{H} 2$, the pattern is generally one where the youth is most active, while older citizens are only more active in a couple of the countries. Confirming also H3, non-citizens are almost everywhere more active in support of other people in European countries. $\mathrm{H} 4$ is also confirmed by and large with higher resources in terms of education linked to greater engagement, although in some countries, individuals in some of the lower classes are also quite engaged in comparison with those in professional classes. We also find support for $\mathrm{H} 5$ with those more involved in organisations and with higher social trust more engaged. H6 on political interest is also confirmed, though evidence for $\mathrm{H} 7$ on voting is more mixed and more specific to some countries; $\mathrm{H} 8$ on leftist identification is also supported. $\mathrm{H} 9$ on religiosity and $\mathrm{H} 10$ on attachment to the EU are also confirmed with respect to greater engagement.

Finally, we turn to Table 2.10, which shows odd ratios and includes all variables discussed above to see which effects remain strong net of the others. Here we find strong age effects (H2) with middle aged and older individuals significantly less likely to engage than the younger respondents partially confirming biographical availability theorising. We also find strong effects (H3) of non-citizen status, thus also confirming findings from the 
Table 2.9 Determinants of support for other Europeans (in \%). "Have you ever done one of the following in order to support the rights of people/groups in other countries within the European Union?"

\begin{tabular}{|c|c|c|c|c|c|c|c|c|}
\hline & DK & FR & $\mathrm{DE}$ & EL & IT & PL & $\mathrm{CH}$ & UK \\
\hline \multicolumn{9}{|l|}{ Gender } \\
\hline Male & 23 & 28 & 34 & 38 & 35 & 35 & 33 & 17 \\
\hline Female & 24 & 23 & 29 & 32 & 28 & 34 & 36 & 20 \\
\hline \multicolumn{9}{|l|}{ Age groups } \\
\hline $18-34$ & 31 & 32 & 38 & 30 & 39 & 33 & 36 & 35 \\
\hline $35-54$ & 21 & 25 & 29 & 35 & 30 & 34 & 33 & 17 \\
\hline $55+$ & 20 & 22 & 29 & 38 & 29 & 37 & 35 & 9 \\
\hline \multicolumn{9}{|l|}{ Citizen status } \\
\hline Not citizen & 40 & 42 & 35 & 19 & 52 & 52 & 42 & 36 \\
\hline Citizen & 23 & 25 & 31 & 35 & 31 & 34 & 33 & 18 \\
\hline \multicolumn{9}{|l|}{ Education level } \\
\hline University+ & 30 & 29 & 36 & 41 & 41 & 38 & 40 & 26 \\
\hline Completed secondary & 24 & 28 & 32 & 37 & 31 & 34 & 32 & 17 \\
\hline Less than secondary & 18 & 21 & 25 & 30 & 30 & 34 & 33 & 14 \\
\hline \multicolumn{9}{|l|}{ Class chief earner } \\
\hline Professional & 30 & 31 & 35 & 41 & 42 & 45 & 41 & 24 \\
\hline Manager/Sr Adm & 27 & 29 & 39 & 42 & 45 & 45 & 35 & 21 \\
\hline Clerical & 17 & 23 & 28 & 42 & 29 & 33 & 32 & 15 \\
\hline Sales or Services & 23 & 28 & 37 & 42 & 38 & 34 & 30 & 35 \\
\hline Foreman/Superv & 30 & 24 & 25 & 39 & 43 & 37 & 31 & 10 \\
\hline Skilled Manual & 26 & 30 & 25 & 31 & 24 & 31 & 33 & 13 \\
\hline Semi-/Unskilled & 18 & 20 & 24 & 26 & 21 & 24 & 35 & 15 \\
\hline Other, e.g., farming & 21 & 17 & 21 & 19 & 28 & 28 & 26 & 18 \\
\hline \multicolumn{9}{|l|}{ Association member } \\
\hline No & 15 & 19 & 23 & 26 & 18 & 26 & 26 & 9 \\
\hline Yes & 39 & 49 & 51 & 44 & 57 & 61 & 45 & 48 \\
\hline \multicolumn{9}{|l|}{ Social trust } \\
\hline No & 22 & 23 & 25 & 32 & 28 & 32 & 30 & 15 \\
\hline Yes & 25 & 35 & 43 & 46 & 42 & 44 & 41 & 25 \\
\hline \multicolumn{9}{|l|}{ Political interest } \\
\hline No & 18 & 19 & 19 & 29 & 21 & 28 & 29 & 11 \\
\hline Yes & 27 & 30 & 35 & 40 & 38 & 38 & 38 & 23 \\
\hline \multicolumn{9}{|l|}{ Voted } \\
\hline No & 27 & 26 & 26 & 33 & 33 & 28 & 35 & 27 \\
\hline Yes & 23 & 25 & 33 & 36 & 31 & 37 & 34 & 17 \\
\hline \multicolumn{9}{|l|}{ Leftist } \\
\hline No & 19 & 23 & 28 & 32 & 29 & 32 & 30 & 15 \\
\hline Yes & 32 & 33 & 37 & 43 & 36 & 42 & 45 & 29 \\
\hline \multicolumn{9}{|l|}{ Religious } \\
\hline No & 22 & 23 & 28 & 41 & 29 & 33 & 32 & 16 \\
\hline Yes & 26 & 31 & 40 & 31 & 35 & 36 & 39 & 26 \\
\hline \multicolumn{9}{|l|}{ Attached to EU } \\
\hline No & 19 & 21 & 25 & 31 & 27 & 26 & 30 & 10 \\
\hline Yes & 31 & 30 & 37 & 42 & 37 & 39 & 46 & 33 \\
\hline
\end{tabular}

Source: TransSOL (Horizon 2020, GA, no. 649435) 
Table 2.10 Multivariate logistic regression on support for other Europeans (odds ratios)

\begin{tabular}{|c|c|}
\hline Gender & \\
\hline Male & $\mathrm{RC}$ \\
\hline Female & .98 \\
\hline Age groups & \\
\hline $18-34$ & $\mathrm{RC}$ \\
\hline $35-54$ & $.80^{* * *}$ \\
\hline $55+$ & $.66^{* * *}$ \\
\hline Citizen status & \\
\hline Citizen & $.67 * * *$ \\
\hline Education level & \\
\hline University+ & $\mathrm{RC}$ \\
\hline Completed secondary & .98 \\
\hline Less than secondary & .98 \\
\hline Class chief earner & \\
\hline Professional & $\mathrm{RC}$ \\
\hline Manager/Sr Adm & .99 \\
\hline Clerical & $.83^{* *}$ \\
\hline Sales or Services & .97 \\
\hline Foreman/Supervisor & .86 \\
\hline Skilled Manual & .89 \\
\hline Semi-/Unskilled & $.71^{* * *}$ \\
\hline Other, e.g., farming & $.74 * * *$ \\
\hline Association member & \\
\hline Yes & $3.28 * * *$ \\
\hline Social trust & \\
\hline Yes & $1.39^{* * *}$ \\
\hline Political interest & \\
\hline Yes & $1.36^{* * *}$ \\
\hline Voted & \\
\hline Yes & .92 \\
\hline Leftist & \\
\hline Yes & $1.34^{* * *}$ \\
\hline Religious & \\
\hline Yes & $1.17^{* * *}$ \\
\hline Attached to EU & \\
\hline Yes & $1.56^{* * *}$ \\
\hline Country & \\
\hline Denmark & $\mathrm{RC}$ \\
\hline France & $1.42 * * *$ \\
\hline Germany & $1.50 * * *$ \\
\hline Greece & $1.91 * * *$ \\
\hline Italy & $1.65^{* * *}$ \\
\hline Poland & $2.00^{* * *}$ \\
\hline Switzerland & $1.64^{* * *}$ \\
\hline UK & $.78^{* * *}$ \\
\hline $\mathrm{N}$ & 16,239 \\
\hline Loglikelihood & -8841.6309 \\
\hline
\end{tabular}


literature in regard to the importance of transnational networks, into which citizens with a migrant background are more likely to be involved. We find some support for $\mathrm{H} 4$ on resources with respect to class with those in clerical, semi or unskilled manual and other (e.g., farming) occupations all less likely to engage than individuals in the professional classes. Associational involvement increased the likelihood of engagement by over three times and more socially trusting individuals were also more likely to engage (H5). Those politically interested were more likely to engage (H6), as were those with leftist values (H8), religious beliefs (H9) and those with strong attachments to the EU (H10). We also found some interesting country differences with citizens in six countries more likely to engage than those in either Denmark or the UK (the latter to an even lesser extent).

\subsection{CONCLUSION}

The various crises affecting the European Union since 2008 have underlined the need for solidarity between European governments. In addition, the consequences of the Great Recession and the immigration of refugees fleeing from war, persecution and poverty have seemingly called for immediate remedial actions also by European citizens themselves. The aim of this chapter was to provide empirical evidence on two main questions related to this observation. How strong is this private form of social solidarity within the European citizenry? And how generalised is the readiness of Europeans to help others in need?

The empirical evidence presented in this chapter gives a mixed picture about transnational solidarity in Europe. We found that a strong majority of respondents supports the attempts of the EU to help countries outside of Europe in fighting poverty and promoting development. And European citizens strongly support solidarity-based (redistributive) public policies, with almost three-quarters considering the reduction of big income inequalities as an important goal. In other words, the traditional European social model is not questioned by respondents. However, the strong public support of institutionalised solidarity in terms of state-led policies of humanitarian aid and social redistribution does not necessarily translate to vivid support for solidarity within the EU.

In fact, the readiness of the European population to support solidarity between member states of the EU is more limited when addressing financial assistance to countries with public debts and higher numbers of refugees. Additionally, citizens are involved in solidarity activities to a considerable extent, but they are engaged more in support of fellow citizens - and people living outside of Europe - than on behalf of fellow 
Europeans. The findings show that European solidarity is guiding the behaviour of a significant minority of respondents, i.e., one in every three European citizens. However, for the majority, solidarity in Europe is rather a matter of subsidiarity, and thus a matter of national policies and solidarity support among fellow citizens.

Proponents of European solidarity activism are younger and in a privileged occupational situation; they have acquired more extensive social capital in terms of associational involvement and trust, they lean towards the political left, are more religious and identify clearly with Europe. At the same time, less privileged citizens are less likely to be engaged in European solidarity, even though this does not mean that they are explicitly against it. For them, national solidarity seems to be a more reliable and important issue. Consequently, European solidarity still seems to be patterned along social and cultural divisions (see also Gerhards et al., 2019).

These findings generally confirm what scientific studies have said about the levels and drivers of civic engagement, voluntarism and political behaviour at large (Wilson, 2000; Cainzos and Voces, 2010; Bauer et al., 2013; Grasso, 2013; Giugni and Grasso, 2015). And this means that European solidarity does not greatly deviate from the picture research has painted about social and civic solidarity in general. Before this backdrop, we might expect that the general challenge faced by proponents of European solidarity is rather its low level of institutionalisation within the EU. Perhaps many Europeans do not see the EU as an accomplished political community establishing and guaranteeing common rights and mutual obligations. European solidarity seems to be more diffused among citizens sharing a more inclusive and open conception of European citizenship (Kurowska et al., 2019; Lahusen and Theiss, 2019). Giving solidarity more institutional weight within the EU might also be an instrument of reaffirming that solidarity is an important baseline of European citizenship.

\section{REFERENCES}

Alesina, A. and Giuliano, P. (2011). Preferences for Redistribution. In J. Benhabibi, A. Bisin and M. Jackson (eds), Handbook of Social Economics. San Diego: North-Holland, pp. 93-132.

Alesina, A. and Glaeser, E. (2004). Fighting Poverty in the US and Europe: A World of Difference. Oxford: Oxford University Press.

Amat, F. and Wibbels, E. (2009). Electoral Incentives, Group Identity and Preferences for Redistribution. Instituto Juan March de Estudios e Investigaciones Working Paper 246.

Arts, W. and Gelissen, J. (2001). Welfare States, Solidarity and Justice Principles: Does the Type Really Matter? Acta Sociologica, 44(4): 283-99. 
Baglioni, S. and Giugni, M. (eds) (2014). Civil Society Organizations, Unemployment, and Precarity in Europe: Between Service and Policy. Basingstoke: Palgrave Macmillan.

Balibar, É. (2010). Europe: Final Crisis? Some Theses. Theory \& Event, 13(2): Project MUSE.

Balme, R. and Chabanet, D. (2008). European Governance and Democracy: Power and Protest in the EU. Lanham, MD: Rowman \& Littlefield.

Banting, K. G. and Kymlicka, W. (eds) (2006). Multiculturalism and the Welfare State: Recognition and Redistribution in Contemporary Democracies. Oxford: Oxford University Press.

Bauer, T. K., Bredtmann, J., and Schmidt, C. M. (2013). Time vs. Money - The Supply of Voluntary Labor and Charitable Donations across Europe. European Journal of Political Economy, 32: 80-94.

Baute, S., Meuleman, B., Abts, K. and Swyngedouw, M. (2018). Measuring Attitudes towards Social Europe: A Multidimensional Approach. Social Indicators Research, 137(1): 353-78.

Beck, U. and Grande, E. (2007). Cosmopolitan Europe. Cambridge: Polity Press.

Beyerlein, K. and Bergstrand, K. (2013). Biographical Availability. In D. A. Snow, D. della Porta, B. Klandermans, and D. McAdam (eds), The Wiley-Blackwell Encyclopedia of Social and Political Movements. New York: Wiley-Blackwell, pp. $137-8$.

Blekesaune, M. and Quadagno, J. (2003). Public Attitudes toward Welfare State Policies: A Comparative Analysis of 24 Countries. European Sociological Review, 19(5): 415-27.

Brady, H. E., Verba, S., and Schlozman, K. L. (1995). Beyond SES: A Resource Model of Political Participation. The American Political Science Review, 89(2): 271-94.

Cainzos, M. and Voces, C. (2010). Class Inequalities in Political Participation and the 'Death of Class' Debate. International Sociology, 25(3): 383-418.

Chan, J., To, H. and Chan, E. (2006). Reconsidering Social Cohesion: Developing a Definition and Analytical Framework for Empirical Research. Social Indicators Research, 75: 273-302.

de Witte, F. (2015). Justice in the EU: The Emergence of Transnational Solidarity. Oxford: Oxford University Press.

Delanty, G. and Rumford, C. (2005). Rethinking Europe: Social Theory and the Implications of Europeanization. Abingdon and New York: Routledge.

Delhey, J. (2007). Do Enlargements Make the European Union Less Cohesive? An Analysis of Trust between EU Nationalities. Journal of Common Market Studies, 45(2): 253-79.

della Porta, D. (2018). Solidarity Mobilizations in the 'Refugee Crisis': Contentious Moves. Cham: Palgrave Macmillan.

della Porta, D. and Caiani, M. (2011). Social Movements and Europeanization. Oxford: Oxford University Press.

Eurobarometer (2011). Financial and Economic Crisis, Financial Services, Corruption, Development Aid, and Gender Equality. Brussels: European Commission, DG Communication (no. 76.1).

Evangelinidis, A. (2016). The Greek State's Response to the Refugee Crisis and the Solidarity Movement. Contemporary Southeastern Europe, 3(1): 32-6.

Fong, C. (2001). Social Preferences, Self-Interest, and the Demand for Redistribution. Journal of Public Economics, 82(2): 225-46. 
Gelissen, J., Wim, J. H., van Oorschot, W. and Finsveen, E. (2012). How Does the Welfare State Influence Individuals' Social Capital? Eurobarometer Evidence on Individuals' Access to Informal Help. European Societies, 14(3): 416-40.

Gerhards, J., Lengfeld, H., Ignácz, Z. S., Kley, F. K. and Priem, M. (2018). How Strong is European Solidarity? Berlin Studies on the Sociology of Europe (BSSE), 37: 1-37.

Gerhards, J., Holger, L., Zsófia, I., Kley, F. K. and Priem, M. (2019). European Solidarity in Times of Crisis: Insights from a Thirteen-Country Survey. London: Routledge.

Gesthuizen, M., van der Meer, T. and Scheepers, P. (2008). Education and Dimensions of Social Capital: Do Educational Effects Differ due to Educational Expansion and Social Security Expenditure? European Sociological Review, 24(5): 617-32.

Giugni, M. and Grasso, M. (eds) (2015). Austerity and Protest: Popular Contention in Times of Economic Crisis. London: Routledge.

Giugni, M. and Grasso, M. T. (2016). How Civil Society Actors Responded to the Economic Crisis: The Interaction of Material Deprivation and Perceptions of Political Opportunity Structures. Politics \& Policy, 44(3): 447-72.

Giugni, M. and Grasso, M. T. (2019). Do Unto Others? Individual-Level Mechanisms of Political Altruism. American Behavioral Scientist, 63(4): 430-43.

Giugni, M. and Passy, F. (eds) (2001). Political Altruism? Solidarity Movements in International Perspective. Lanham, MD: Rowman \& Littlefield.

Glick Schiller, N., Basch, L. and Szanton-Blanc, C. (1995). From Immigrant to Transmigrant: Theorizing Transnational Migration. Anthropological Quarterly, 68(1): 48-63.

Grasso, M. T. (2013). The Differential Impact of Education on Young People's Political Activism: Comparing Italy and the United Kingdom. Comparative Sociology, 12(1): 1-30.

Grasso, M. T. and Giugni, M. (2016). Protest Participation and Economic Crisis: The Conditioning Role of Political Opportunities. European Journal of Political Research, 55(4): 663-80.

Habermas, J. (2017). Why the necessary cooperation does not happen: Introduction to a conversation between Emmanuel Macron and Sigmar Gabriel on Europe's future. Paper presented at the Hertie School of Governance in Berlin, 16 March 2017, https://www.socialeurope.eu/2017/03/pulling-cart-mire-renewed-case-euro pean-solidarity/, last accessed 09.05.2017.

Iversen, T. and Soskice, D. (2001). An Asset Theory of Social Policy Preferences. American Political Science Review, 95(4): 875-93.

Jaime-Castillo, A. (2013). Public Opinion and the Reform of the Pension Systems in Europe: The Influence of Solidarity. Journal of European Social Policy, 23(4): 390-405.

Jeannotte, M. S. (2000). Social Cohesion around the World: An International Comparison of Definitions and Issues. Paper SRA-390.

Jenkins, J. C. (1983). Resource Mobilization Theory and the Study of Social Movements. Annual Review of Sociology, 9: 527-53.

Komter, A. E. (2005). Social Solidarity and the Gift. Cambridge: Cambridge University Press.

Kriesi, H. and Pappas, T. S. (eds) (2015). European Populism in the Shadow of the Great Recession. Colchester: ECPR Press.

Kronauer, M. (1998). 'Social Exclusion' and 'Underclass': New Concepts for 
the Analysis of Poverty. In H. J. Andreß (ed.), Empirical Poverty Research in a Comparative Perspective. Aldershot, UK and Brookfield, VT: Ashgate, pp. $51-75$.

Kumlin, S. and Rothstein, B. (2005). Making and Breaking Social Capital: The Impact of Welfare-State Institutions. Comparative Political Studies, 38(4): 339-65.

Kurowska, A., Eisele, O. and Kiess, J. (2019). Welfare Attitudes and Expressions of (Trans)national Solidarity. American Behavioral Scientist, 63(4): 492-505.

Lahusen, C. (2013). European Integration, Social Cohesion and Political Contentiousness. In B. Andreosso-O'Callaghan and F. Royall (eds), Economic and Political Change in Asia and Europe: Social Movement Analyses. Dordrecht: Springer, pp. 31-52.

Lahusen, C. and Theiss, M. (2019). European Transnational Solidarity: Citizenship in Action? American Behavioral Scientist, 63(4): 444-58.

Lengfeld, H., Schmidt, S. and Häuberer, J. (2012). Solidarität in der europäischen Fiskalkrise: Sind die EU-Bürger zu finanzieller Unterstützung von hoch verschuldeten EU-Ländern bereit? Erste Ergebnisse aus einer Umfrage in Deutschland und Portugal. University of Hamburg: Hamburg Reports on Contemporary Societies No. 5/2012.

Lengfeld, H., Schmidt, S. and Häuberer, J. (2015). Is There a European Solidarity? Attitudes Towards Fiscal Assistance for Debt-Ridden European Union Member States. Report No. 67, 1 April, University of Leipzig.

Lichterman, P. (2015). Religion and Social Solidarity: A Pragmatist Approach. In L. Hustinx, J. von Essen, J. Haers and S. Mels (eds), Religion and Volunteering: Complex, Contested and Ambiguous Relationships. Cham: Springer, pp. 241-61.

Likki, T. and C. Staerklé (2014). A Typology of Ideological Attitudes towards Social Solidarity and Social Control. Journal of Community and Applied Social Psychology, 24: 406-21.

Luttmer, B. (2001). Group Loyalty and the Taste for Redistribution. Journal of Political Economy, 109(3): 500-528.

Maio, G. R., Olson, J. M., Bernard, M. M. and Luke, M. A. (2006). Ideologies, Values, Attitudes, and Behavior. In J. Delamater and A. Ward (eds), Handbook of Social Psychology, Handbooks of Sociology and Social Research. Boston, MA: Springer, pp. 283-308.

Mau, S. (2005). Democratic Demand for a Social Europe? Preferences of the European Citizenry. International Journal of Social Welfare, 14(2): 76-85.

Mau, S. (2006). Forms and Prospects of European Solidarity. In N. Karangiannis (ed.), European Solidarity. Liverpool: Liverpool University Press, pp. 129-46.

Mau, S. and Burkhardt, C. (2009). Migration and Welfare State Solidarity in Western Europe. Journal of European Social Policy, 19(3): 213-29.

Morokvasic, M. (1999). La mobilité transnationale comme ressource: le cas des migrants de l'Europe de l'Est. Cultures et Conflits, 32: 105-22.

Neill, B. and Gidengil, E. (eds) (2006). Gender and Social Capital. New York: Routledge.

Putnam, R., Feldstein, L. M. and Cohen, D. (2003). Better Together: Restoring the American Community. New York: Simon \& Schuster.

Recchi, E. and Favell, A. (2009). Pioneers of European Integration: Citizenship and Mobility in the EU. Cheltenham, UK and Northampton, MA, USA: Edward Elgar Publishing. 
Rehm, P. (2009). Risks and Redistribution: An Individual-Level Analysis. Comparative Political Studies, 42(7): 855-81.

Rehm, P., Hacker, J. S. and Schlesinger, M. (2012). Insecure Alliances: Risk, Inequality and Support for the Welfare State. American Political Science Review, 106(2): 386-406.

Scheepers, P. and Grotenhuis, M. T. (2005). Who Cares for the Poor in Europe? Micro and Macro Determinants for Alleviating Poverty in 15 European Countries. European Sociological Review, 21(5): 453-65.

Smith, J. (1997). Transnational Social Movements and Global Politics: Solidarity beyond the State. Syracuse, NY: Syracuse University Press.

Sotiropoulos, D. A. and Bourikos, D. (2014). Economic Crisis, Social Solidarity and the Voluntary Sector in Greece. Journal of Power, Politics \& Governance, 2(2): $33-53$.

Stegmueller, D., Scheepers, P., Roßteuscher, S. and de Jong, E. (2012). Support for Redistribution in Western Europe: Assessing the Role of Religion. European Sociological Review, 28(4): 482-97.

Stets, J. E. and McCaffree, K. (2014). Linking Morality, Altruism, and Social Solidarity Using Identity Theory. In Vincent Jeffries (ed.), The Palgrave Handbook of Altruism, Morality, and Social Solidarity. New York: Palgrave Macmillan, pp. 333-51.

Stjernø, S. (2012). Solidarity in Europe: The History of an Idea. Cambridge: Cambridge University Press.

Svallfors, S. (1997). Worlds of Welfare and Attitudes to Redistribution: A Comparison of Eight Western Nations. European Journal of Sociology, 13(3): 283-304.

Thielemann, E. R. (2003). Between Interests and Norms: Explaining BurdenSharing in the European Union. Journal of Refugee Studies, 16(3): 253-73.

Valentova, M. (2016). How Do Traditional Gender Roles Relate to Social Cohesion? Focus on Differences Between Women and Men. Social Indicators Research, 127(1): 153-78.

van Oorschot, W. (2000). Who Should Get What, and Why? On Deservingness Criteria and the Conditionality of Solidarity among the Public. Policy \& Politics, 28(1): 33-48.

van Oorschot, W. (2006). Making the Difference in Social Europe: Deservingness Perceptions among Citizens of European Welfare States. Journal of European Social Policy, 16(1): 23-42.

van Oorschot, W. and Arts, W. (2005). The Social Capital of European Welfare States: The Crowding Out Hypothesis Revisited. Journal of European Social Policy, 15(1): 5-26.

van Oorschot, W., Arts, W. and Gelissen, J. (2006). Social Capital in Europe: Measurement and Social and Regional Distribution of a Multifaceted Phenomenon. Acta Sociologica, 49: 149-67.

Verba, S., Nie, N. and Kim, J. (1978). Participation and Political Equality: A SevenNation Comparison. London: Cambridge University Press.

Wheeless, L. R. (1978). A Follow-up Study of the Relationship Among Trust, Disclosure, and Interpersonal Solidarity. Human Communication Research, 4(2): 143-57.

Wilson, J. (2000). Volunteering. Annual Review of Sociology, 26: 215-40. 